\title{
Wildlife in Managed Forests - A Matter of Commitment
}

\author{
by \\ Jack Ward Thomas, Chief Research Wildlife Biologist, USDA Forest Service
}

\begin{abstract}
Providing for wildlife habitat in managed requires commitment of forest managers and land owners. There will be costs associated with maintenance of wildlife habitats. Who bears those costs is a matter to be settled. The maintenance of wildlife in the managed forest is apt to be a litmus test for acceptable attention to environmental concerns by forest managers.
\end{abstract}

\section{Introduction}

I have read many definitions of what is a conservationist, and written not a few myself, but I suspect that the best one is written not with a pen, but with an axe. It is a matter of what man thinks about while chopping, or deciding what to chop. A conservationist is one who is humbly aware that with each stroke he is writing his signature on the face of the land. Signatures of course differ, whether written with axe or pen, and this is as it should be" (Leopold 1949:68).

All across North America, the remaining virgin forests are being rapidly brought under management. These forests are being manipulated to produce products desired by people. The resulting forest - indeed the landscape that emerges is formulated by what ". . . man thinks about while chopping." That is not a new thought. But, it is a thought that has only recently been expanded to include consideration of wildlife habitat and is just now being incorporated into forest management.

For too long those interested in forest management ascribed to such platitudes as "good forest management [i.e., management for timber production] is good wildlife management." Such statements served as a soothing syrup to make single-use forestry practices more palatable (Bunnell 1976). Fortunately, such bromides are less frequently heard these days.

Yet, the battered concept of multiple-use forestry is still held up as an ideal - not because forest managers have done an acceptable job of practicing multiple-use forestry, but because the idea is a good one. The technical capability to actually practise multiple-use forestry exists. All that is lacking is the willingness and ability to commit the necessary resources and to bear the necessary direct and opportunity costs.

The maintenance of wildlife diversity and the enhance- ment of the welfare of selected species of wildlife can be products from managed forests. Further, this is apt to be the criterion on which the body politic judges the ability of forest managers to produce wood while maintaining forests in an acceptable state. Wildlife, because of its beauty, because people are interested in and cherish wildlife, may very well be the emerging surrogate for many other forest values besides wood.

If there is insensitivity to this phenomenon, there will likely be, sooner or later, retribution from the public in the form of constraints on the prerogatives of forest managers to practice their craft. This has already occurred in the United States in the form of far-reaching legislation that has directed, in precise terms, that managers of publicly owned forests be more sensitive to the welfare of wildlife. The lives of forest managers in the United States are now considerably more complicated, and forest management more expensive to execute, due to the erosion of their credibility as multiple-use managers (Thomas 1985).

Looking back with $20 / 20$ hindsight, some foresters and wild life biologists in the United States wonder how much of this could have been avoided had there been more concern about wildlife, more sensitivity to the growing public concern and interest in wildlife, and more recognition that they practiced their craft of forest management in a democratic society and to large extent on publicly owned land.

\section{Multiple-Use Forestry Essential}

It is far better, over the long run, to practise a style of forest management that is sensitive to the desires of the public. Among the first tests to be passed will be the maintenance of wildlife diversity and production of selected species of wildlife from managed forests. The second, and not far behind, will be the appearance of the landscape that emerges as the forests reach a fully regulated state. If forest managers fail these tests in the public's eye, it seems that constraints on the prerogatives of forest managers may be imposed through the political process to ensure attention to the welfare of wildlife and to the esthetics of the emerging forest landscape.

The forest, whether managed or unmanaged, is wildlife habitat. No matter what the forest manager does, the forest will continue to be wildlife habitat. But habitat for what species and of what quality? 
So far as wildlife habitat is concerned, the forest manager has two choices - take whatever comes or design the emerging managed forest to achieve wildlife objectives. Those objectives should be clearly stated and considered as a co-product of wood fibre from the managed forest. Under no circumstances should wildlife objectives be considered a constraint on the production of wood. There is a subtle, but absolutely critical, difference in the management viewpoint between being a desired product and a constraint. Such a change in thinking is critical to the achievement of true multiple-use forestry (Thomas 1985).

Unfortunately, at the moment, foresters and wildlife biologists are, far too often, antagonists in the game of forest management. The forester is placed in the role of meeting targets for wood production in the most efficient manner (usually over the short run). The wildlife biologist strives to save as much habitat for wildlife as possible (also over the short run). Ergo, wildlife objectives and wildlife biologists are too often viewed by forest managers as, respectively, constraints and constrainers. Commercial forest managers are, at this juncture of history, driven to large extent by the need to achieve acceptable profit margins. This usually means maximum production of wood at the lowest costs.

That is a formula for frustration, failure, and conflict. There has to be a better way - and fortunately, there is. First, there must be a clearly stated set of goals and objectives, for both short and long term, for the simultaneous production of wood and wildlife. These goals and objectives must be derived through politically acceptable process. Considering the long term, it is essential in a democracy that the majority of the concerned publics agree with the goals and objectives set for forest management or there will be increasing conflict and disruption. This can be achieved either by participation of the concerned publics in developing those goals and objectives or by the publics being brought into agreement through education or both.

\section{Forestry/Wildlife Partnership}

Foresters and wildife biologists must work as partners to accomplish the objectives for timber production and wildife habitat in the managed forest. That means the establishment of a partnership of professional equals - anything less will ultimately disintegrate into animosity and destructive game playing (Thomas 1985).

This partnership will be an uneasy one - at least initially. The forest manager will carry out operations in the welldefined world of cost-benefit considerations and bottom lines on ledger sheets. It is much easier to practise coherent accounting when dealing with products from the forest that have clearly defined market values; i.e., wood products. Most wildlife does not have a market value, and benefits from wildlife are usually estimated by various indirect methods, such as estimates of the amount of money spent by hunters, the stated willingness to pay and how much, or the travel costs associated with hunting or fishing. Such estimates don't seem to carry much weight with decision makers. Yet, many of those decision makers have learned that wildlife is highly valuable to the public and in the ecological sense. The conflict over economic analyses in the management of natural resources will continue until the art and science of economic analysis becomes mature enough and sophisticated enough to deal with the question of how to consider nonmarket-valued products in analyzing alternatives in forest management.
Many of the laws of ecology, or economics for that matter, can be succinctly summarized by the statements: (1) everything is connected to everything else, and (2) there is no such thing as a free lunch (Commoner 1971). There is no forestry action that does not have an impact on wildlife - some positive and some negative (Thomas 1979a). Few alterations in forest management schemes (initially designed to maximize wood production) are made to benefit wildlife that do not have some adverse effect on either the production of wood, the efficiency of that production, the ease of operations, or all three. To pretend otherwise is to build a dream world that will evaporate with experience. It is not possible to meet wildlife objectives with no effect on wood production certainly not everywhere and all the time. That simply means that if both timber and wildlife are produced from the same area at politically and economically acceptable levels neither is likely to be at maximum.

Determination of what that level for the production of these joint products should be is the tricky part. It is an exercise in biological, economic, political, and social acumen. It is not a problem to be solved through biologic and economic analysis alone. Applied biology, whether forestry or wildlife management, is not pure - each practitioner views the world through a set of lenses with an individual prescription determined by education, expereince, bias, and the objective of the employer. And, politics is the way public matters are settled in a democracy. The practice of the biopolitical game that is forest management involves compromise and tradeoffs (Thomas 1984). That's the way it is. There seems to be little profit in pretending or wishing otherwise.

The fundamental reason for timber-wildlife conflicts is differing macroeconomic goals. The tacit macroeconomic goal for timber management is to maximize profits under whatever circumstances prevail. Thereby, the appropriate guage to judge economic costs and benefits is present net value (PNV) of the forest under consideration. This is, by definition, a purely economic criterion and is not adequate by itself for making decisions in multiple-use forestry.

In formulating goals and objectives for wildlife, the criteria for success are usually the achievement of such goals as maintenance of species diversity or a sustained yield of some select species over time. Therefore, the criterion for decision making is maintenance of a habitat condition (or conditions) over time. It should not be a surprise, then, that a short-term decision to maximize PNV is likely in conflict with long-term habitat maintenance for wildlife.

These conflicts in macromanagement must be recognized and resolved at the highest levels of government and corporate management. Otherwise, micromanagers or forest level managers have an impossible job. Can the manager operating without guidance on what is expected in terms of attention to wild life concerns make optimum timberwildlife decisions and survive in a system where profit, or lack of it, is the ultimate means of keeping score? Not likely.

\section{Rules of the Game - Who Pays}

Micromanagers must operate with the same rules and similar objectives for deriving and meeting goals and objectives for wildlife. There must be a statement of societal objectives for wildlife on forest lands - most particularly publicly owned lands. It is irrational to expect managers who are ultimately judged by financial ledgers to intentionally 
absorb opportunity and direct costs to benefit wildlife that reduces profit - particularly if that manager has no idea of what competititors may be doing in this regard.

Guidelines for maintaining and producing wildlife, particularly from Crown lands, need to be established to ensure an equally competitive position for the managing companies involved. This could be done by agreement between the managing entities with appropriate consultation with the involved governments and appropriate technicians, or through government edict.

There are costs, both direct and opportunity, to achieve goals and objectives for wildlife. Such costs detract from profits that would accrue if timber were the sole objective. Incurring costs for wildlife production can negatively influence the competitiveness of wood products in international trade. How these costs are handled - whether they are subsidized or merely absorbed - is a matter of governmental policy.

Once macromanagement decisions and how wildlife and wildlife habitats are to be treated and who will pay the costs are made, the micromanagers have a job to do that they have the skills and direction to accomplish. The impossible becomes possible.

This presents forest managers with a paradox. If wildlife is a desired product from managed forests - it should be considered just that and not a constraint. On the other hand, if a company or corporation is charged with producing wildlife, which is desired by society at large, it can only do so by incurring the direct and opportunity costs of producing that wildlife. Therefore, wildlife becomes a constraint; it shouldn't be but it is.

Is there any way out of this paradoxical situation? Several come to mind. There could be compensation to the managing entity - whether direct or in terms of concessions. There could be clearly spelled out responsibilities in terms of wildlife production and habitat consideration. In that case all the managing entities absorb the costs equally and there are no questions of equity - i.e., production of wildlife is one more cost of doing business and all companies share similar costs. However, these costs are still a constraint on profit.

I am not familiar enough with the Canadian situation to prescribe an answer and it would be presumptuous to do so. I can, however, recognize the quandary. It must be addressed and solved if the desire for the production of wood and wildlife from the same managed forests is to be recognized over the long-term. Wildlife objectives will not be met in the managed forest without costs - sometimes high costs. Who pays those costs? That question cannot be avoided for long and a satisfactory answer is critical to success.

\section{Need for Knowledge}

In setting wildlife goals and objectives for the managed forest that mean anything in practice, it must be assumed that sufficient knowledge exists about the relationship of various practices and forest conditions to the spectrum of resident wildlife. That knowledge must exist in a form that can be used in analyzing various alternative forest management schemes. Two problems arise: (1) the knowledge about how many species react to habitat is nonexistent or woefully weak; and (2) such information as does not exist has not been integrated into a form that can be used in forest planning and management. There has been some first efforts made in the United States to put wildlife habitat data in such a form (Brown
1985, Hoover and Wills 1984, Verner and Boss 1980, Thomas 1979a).

Canada's first such effort of this type is well underway in British Columbia. Given sufficient resources and motivation similar efforts should be instituted elsewhere. The key to such efforts is recognition that:

"Perhaps the greatest challenge that faces professionals
engaged in forest research and management is the
organization of knowledge and insights into forms that
can be readily applied. To say we don't know enough is to
take refuge behind a half-truth and ignore the fact that
decisions will be made regardless of the amount of
information available. In my opinion it is far better to
examine available knowledge, combine it with expert
opinion on how the system operates, and make
predictions about the consequences of alternative
management actions" (Thomas 1979b).

If there is to be a genuine consideration of wildlife in the development of managed forests, the summary and synthesis of wildlife and forestry information is only the place to start. Research must continue apace to fill the gaps in knowledge of how wildlife relates to the habitats characteristic of the managed forest. This is particularly true of species that have economic and sport-hunting value, those that are particularly sensitive to habitat manipulation, and those that are or become threatened or endangered. Failure to maintain an adequate research effort in these areas can have dramatic social and economic consequences as forest management intensifies.

For example, there is a small bird in the Pacific Northwest of the United States called the northern spotted owl (Strix occidentalis). The welfare of this cryptic species, which seems to be largely confined to old-growth Douglas-fir forest stands of some 134-1,340 hectares, is the cause celebre in forest wildlife management in North America. An explosive controversy over appropriate management plans to insure the viability of the spotted owl (and other old-growth dependent species) has developed. Management plans have been done and redone; legal appeals filed; environmental impact statements done and redone at significant costs in money, personnel, time and delays; special "blue ribbon panels" convened; and crash research programs instituted. The knowledge necessary to make management decisions with a high degree of certainty is still not available. There seems to be no end in sight. Costs to date of research unfunded and undone at the appropriate time probably runs to considerably more than $\$ 10$ million with more - probably much more - to come. The reservation of sufficient old-growth forests to assure the welfare of the spotted owl and other species thought to be associated with such habitats has a potential price tag in terms of opportunity costs of at least several billion dollars.

The point is, the scientfic basis for managing wildlife in forests is weak and must be improved. And, the consequences of such ignorance can be, depending on the laws and politics involved, very expensive. Those who think research is too expensive will inevitably pay the price for ignorance. But, I remind you, the scientific basis for forest management particularly over the long term - is also weak. This does not mean that North Americans will desist from converting virgin forest lands to a managed state - we won't. It does mean that forest managers ought to proceed with a keen awareness that 
there is much that is not known and much that is known that is not completely understood.

\section{The Tools}

Given that forest management will occur, the opportunities for alterations in that management to benefit wildlife are great (Thomas 1979a). What tools does the silviculturist use to produce wood? Basically, there are but a few including: silvicultural system employed, size of regeneration cuts, type of regeneration cut, spacing of trees, timing of treatment, arrangement of stands, site preparation, species favored, thinning regime, and rotation age. These are exactly the techniques a wildife biologist would apply in manipulation of forest habitat to achieve wildlife objectives. It is how, when, and where these techniques are applied that represents the potential for achieving joint production of wood and wildlife it is' what the forest manager "thinks about while chopping, or deciding what to chop."

"The time has come to face up to the fact that the harvest of wood, has greater influence on game [wildlife] than any active technique available to the wildlifer. In one sale a forester can ... influence more cover over a longer time than a game [wildlife] manager ... can create ... in a decade..." (Giles 1962:406).

Achievement of jointly derived goals and objectives for wood production and wildife habitats from managed forests can be realized. But, only if these goals and objectives are derived in a politically acceptable manner with full recognition of tradeoffs; if wild life biologists and foresters work as a team; if existing information on wildlife-habitat relationships is summarized and put into usable form; and if an adequately funded and on-going research program continuously fills in gaps in knowledge as they are recognized.

\section{Conclusion}

The question, then, is not can wildlife and wood be produced from the same forests. They can. The question is do forest managers choose to do so. If the answer is "yes," we must make some changes in how forests are managed. Forest managers must think about wildife when they chop and when they decide what to chop. And, the necessary atmosphere and resources to make the job possible must be provided. The job won't be simple. It won't be easy. It won't be cheap. But its the right thing to do from the standpoint of a land-use ethic (Leopold 1949) and, probably, the smart thing from the political standpoint. In a democracy, these are questions for the people and, ultimately, for politicians.

Most managers of renewable natural resources who have considered the ethics of land-use probably accept Leopold's (1949: 224-225) statement that:

"The 'key-log' which must be moved to release the evolutionary process for an ethic is simply this: quit thinking about decent land-use as solely an economic problem. Examine each problem in terms of what is ethically and esthetically right as well as what is economically expedient. A thing is right when it tends to preserve the integrity, stability, and beauty of the biotic community. It is wrong when it tends otherwise.'

If forest managers want to maintain large amounts of forest land in a managed state with minimum political and legal constraints, it is imperative that they succeed in preserving the "integrity, stability and beauty of the biotic community." If forest managers fail it is likely that more and more land will be dedicated to parks, nature reserves, wildife preserves, and wilderness areas.

There are two pressing reasons for forest managers to do a good job of forest-wildlife management: it is good land-use ethics and it's the smart thing to do if the intent is to maintain forest land in production of forest products with minimum constraints on forest managers.

I believe that the North American public ascribes to Leopold's (1949)) land-use ethic though most have never read the words. Further, I believe the public will judge our adherence to that ethic through the surrogate of how good a job we do of maintaining wildlife in the managed forest. We would do well for the forest, for wildlife, for the public, for the credibility of the natural resource management community, and for future generations if we succeed.

\section{References}

Brown, E.R. 1985. Management of wild life and fish habitats in forests of western Oregon and Washington. Portland, OR: USDA For. Serv., Pacific Northwest Region: $332 p$

Bunnell, F.L. 1976. Forestry-wildlife: whither and future. For. Chron. 52(3): 147-149.

Commoner, B. 1971. The closing circle: nature, man and technology New York, NY: Alfred A. Knopt: $325 \mathrm{p}$

Giles, R.H., Jr. 1962. Timber-wildlife coordination concepts for eastern forests. Trans. N. Amer. Wildl. and Natur. Resour. Conf.: 27: $402-412$

Hoover, R.L. and D.L. Wills (ed.). 1984. Managing forested lands for wildlife. Denver, CO: Colorado Division of Wildlife: $459 p$.

Leopold, A. 1949. A Sand County Almanac and Sketches Here and There. New York: Oxford Univ. Press: 68: 224-225.

Thomas, J.W. (ed.). 1979a. Witdlife habitats in managed forests the Blue Mountains of Oregon and Washington. Washington, D.C.: USDA For. Serv:: 510 p

Thomas, J.W. 1979b. Preface. Wildlife habitats in managed forests - the Blue Mountains of Oregon and Washington. Washington, D.C.: USDA For. Serv:: VII-V|II.

Thomas, J.W. 1984. Free-hunting on the public's lands? - an appraisal. Trans. N. Amer. Wildl. and Natur. Resour. Conf.. 49: 455-468.

Thomas, J.W. 1985. Toward the managed forest - going places that we've never been. Wildife Society Bulletin 13: 195-201.

Verner, J. and A.S. Boss. 1980. Catifornia wildlife and their habitats: western Sierra Nevada. Berkeley, CA: USDA For. Serv., Pacific Southwest Forest and Range Experiment Station: Gen. Tech. Rep. PSW-37: 439 p. 